\title{
Innovative and Investment Approach to the Assessment of the Region's Human Capital
}

\author{
Ekaterina Shchetinina \\ Department of Economic and Management \\ Belgorod State Technological University \\ named after V.G. Shukhov \\ Belgorod, Russia \\ schetinina@inbox.ru \\ Alexander Troshin \\ Department of Economic and Management \\ Belgorod State Technological University \\ named after V.G. Shukhov \\ Belgorod, Russia \\ as_troshin@inbox.ru
}

\author{
Yury Bozhkov \\ Department of Economic and Management \\ Belgorod State Technological University \\ named after V.G. Shukhov \\ Belgorod, Russia \\ bun_belgo@mail.ru \\ Irina Kuznetsova \\ Department of Economic and Management \\ Belgorod State Technological University \\ named after V.G. Shukhov \\ Belgorod, Russia \\ irina8295@yandex.ru
}

\begin{abstract}
This article proposes a methodological approach to the assessment of regional human capital based on its innovation and investment component. It is substantiated that it is human capital that is the fundamental factor of economic growth in the regions of our country, capable of ensuring their competitiveness in the future. Approaches for understanding human capital are summarized, the structure of the region's human capital is analyzed, on the basis of which a qualitative and quantitative approach to its assessment is formed, which most clearly reflects the innovative and investment components of the formation and development of human capital at the regional level. Assessment of the region's human capital is of the most important national economic importance, serving for the purposes of strategic management of territories and planning investments in the reproduction of resources at the meso-level. The necessity of adjusting investments in human capital using the coefficients of quality and innovativeness of the region's human capital introduced by the authors is substantiated; the composition and content of the coefficients proposed in the method are presented. Some results of assessing the human capital of the Belgorod region according to the proposed method are presented.
\end{abstract}

Keywords-human capital, region, innovative person, assessment of human capital of region, quality ratios of human capital of region.

\section{INTRODUCTION}

The innovative model of economic management and socio-economic relations involves the creative transformation of information and accumulated knowledge and skills into various innovations. This high competence is not available to any workforce or collective. In modern conditions, a new type of worker is more necessary than ever, often called today «an innovative person» (V.I. Suprun [1], Yu.N. Bozhkov [2], etc.), who can make non-standard decisions and quickly change the format (communication, interaction, thinking), retains a «fresh» look at processes and phenomena, applies intuition. To achieve this goal, it is no longer enough for the economy to apply skilled labor resources and treat them as a labor force in its previous understanding, it should switch to a fundamentally different perception of its form in the form of human capital of a new type.

In other words, it is necessary to transform the theoretical foundations of research, evaluation and formation of human resources as a very specific form of capital. The problem lies in the search for adequate meters of the qualitative and quantitative characteristics of this type of capital, which is integral from its carrier - the individual. At different levels, this dimension can be different, so our task is to consider approaches to assessing and analyzing human capital at the regional level.

The problem of valuing human capital is fundamentally related historically to the diversity of interpretations of the term «human capital» itself.

Domestic and foreign scientists put forward a variety of definitions of human capital (HC), which can be combined into two main approaches, which, in turn, determine how to evaluate $\mathrm{HC}$ :

- as a set of specific abilities available in a person, which should be rationally used in the production process, namely: knowledge (mental abilities), skills (practical experience), talent, motivation and energy (physical strength) [3];

- as a certain reserve of developed innate and acquired abilities (health, knowledge, skills, motivations, talent) formed as a result of purposeful investments, the rational use of which in the corresponding sphere of social reproduction ultimately contributes to an increase in labor productivity, as well as an increase in the income of a particular individual [4]. 
The first approach focuses on the performance of a person's labor potential, and the second focuses on the identification of various forms, types and distinguishing features of investments in the HC. Both approaches have disadvantages and limitations in practical use, preventing an accurate assessment of the value and quality of the $\mathrm{HC}$ [5]. A synthesis of these approaches is required, that is, a hybrid method involving combining qualitative and quantitative indicators into a single indicator. Such an indicator is necessary, first of all, in strategic regional management, as it would provide an opportunity to assess the competitiveness of the region's human capital (RHC), would allow tracking and refining rating parameters, competently and reasonably investing in this type of capital, fully reproducing and then using it for the benefit of the entire regional community [6]. It must be recognized that the human development index for such goals and targets is not sufficient today [7].

There are separate approaches to structuring individual, regional, national and global human capital. Elements of human capital, depending on the level of aggregation, are named, and then content. For example, individual intellectual capital at the meso-, macro-and mega-level is considered, respectively, as cultural and moral capital, national intellectual advantages and intellectual resources of the world community (L.A. Migranova and M.S. Toksanbaeva [8], S.A. Ayvazyan [9] etc.).

The human capital of a country or a certain region is sometimes divided into spiritual, vital and intellectual. Thus, according to experts, the structure of human capital in the United States is $\$ 95$ trillion or $77 \%$ of the country's national wealth. Vital, spiritual and intellectual components have values respectively - 37\%, 30\%, 33\%. In Russia, these elements were evaluated as follows: vital - $45 \%$, spiritual $47 \%$, intellectual $-8 \%$. The evaluation was carried out at the cost of the State, families, firms and foundations [10].

Note that the human capital of the region, territories as an economic category cannot be identified with the human potential of a country or region, since the concept of capital is wider and has a different economic meaning. This identification is still found in many authors (L.A. Migranova [8], N.M. Rimashevskaya [11], I.V. Soboleva [12], etc.). It can be argued that human potential is one of the most important elements of human capital, but is not equivalent to it.

The value of the $\mathrm{HC}$ at the corporate level is often determined using the Tobin coefficient, which provides for the difference between the market and book value of the capital of the company, correlated with the full-time equivalent [13]. But at the same time it is not disclosed, due to which this difference is achieved, what exactly the parameters of the HC lead to its growth. The quality of the HC is actually reduced only to market estimates of the stock market, where speculative phenomena play a large role.

Based on the presented definitions, it is possible to identify a number of features of the $\mathrm{HC}$ that should be taken into account when studying and understanding the essence of this economic category [2]:

- HC has intangible nature (health, knowledge, abilities, skills, information);

- the occurrence of HC occurs at the moment of interaction of human resources with production factors;
- the HC cannot be transmitted in isolation from its carrier - a particular individual;

- the proceeds from the use of the $\mathrm{HC}$ are controlled by their carrier, regardless of the source of investment;

- the functioning of the $\mathrm{HC}$ is determined directly by the carrier based on personal preferences, interests, connections;

- HC is practically inexhaustible.

At the same time, studies show that the following features are inherent in the $\mathrm{HC}$, as an economic category:

- possibility of accumulation and creation of certain stock of this type of capital;

- providing its carrier with income from its use both now and in the future;

- certain investments are necessary for its development.

The formation of the $\mathrm{HC}$ begins from the individual (carrier) and rises to the regional and state level.

In the current economic environment, the HC plays a key role in achieving economic growth, including at the regional level, acting as the main competitive advantage and potential for innovation, the key to sustainable regional development [14]. A feature of this economic category is that the $\mathrm{HC}$ is able to transform into economic capital, thereby showing the possibility of its accumulation and use. The formation of the $\mathrm{HC}$ takes place through investment in the individual's abilities, as well as by the cost of public time and labor [15].

\section{METHODS}

Modern approaches to the assessment of $\mathrm{HC}$ at the regional level do not seem appropriate without the inclusion of an innovative and investment component in their composition. This is the result of real scientific research by leading scientists and specialists in the field of $\mathrm{HC}$ and is undoubtedly reflected in this work.

The following methods were compiled and applied: systemic, interdisciplinary, monographic, statistical, theoretical generalizations, abstract-logical, index, analysis and synthesis, expert assessments and other general scientific methods.

A representative approach is the generally accepted method of estimating RHC based on the specifics of the Federal State Statistics Service database. Indicators and methods for evaluating elements of the regional $\mathrm{HC}$ are described, in particular, in the works of O.V. Zabelina [16], V.I. Marcinkevich [17] and others. However, with this method, the value of the RHC remains behind the scenes, in addition, it is necessary to update the composition of indicators taking into account new realities and requirements for the quality of work and labor characteristics of the employee.

The proposed methodology will be based on a hybrid method, which involves combining qualitative and quantitative indicators into a single indicator, which helps to give a comprehensive assessment of the RHC with the possibility of taking into account its innovative and investment component. 


\section{MAIN PART}

So, our methodological approach is based on taking into account both the monetary and non-monetary components in the assessment of RHC. The study of relevant sources suggests that the key competence of an innovative person that meets the requirements of the new economy is the ability to create increased value for customers, which is expressed in value added [18]. Therefore, we propose to introduce this important parameter into the integrated assessment of RHC.

Consider the concept of value added in terms of human capital. The modern (2020) Tax Code of the Russian Federation [19] clearly does not disclose the concept of value added, although it is used in the name of tax (VAT). In essence, the tax is paid from the tax base (the value of goods, works, services sold for the period, taking into account excise taxes, but excluding VAT), decreasing by the amount of tax deductions (VAT amounts paid for the same period when purchasing goods, works, services) [20].

In order to begin to «create» value added, you need to adequately present the basic properties of the product, the socalled «must have» corporation, production, industry, region, namely: the ideal or maximum possible quality of the product, due to which it stands out in the category and among competitors. It is clear that such an opportunity is provided by innovation, but not only in technology, but in the very approach to the way to satisfy the needs of the market and modern society [21]

Productivity and quality of work depend on the volume of investments directed and used to ensure the effective implementation of professional skills and production skills of employees, their legal and social protection. At the same time, the prerequisites for the emergence and sources of investments, the peculiarities and mechanisms of their accumulation, as well as changes in the number and nature of work put into motion by them, depend significantly on the strategy of using investments, forms and methods of organizing labor, the distribution of functions at the workplace, and the conditions of production that form productive work [22]. On the formation, development and implementation of the $\mathrm{HC}$ depend on the possibilities of economic growth of the territory, the success of their innovative development.

So, the key ability of a person (collective) today can rightly be called the ability to increase the perceived benefit for an audience - the population or business consumers. The study of empirics allows us to argue that this kind of benefit or value for the client can be created in many areas, especially in those that are traditionally classified as high-value-added industries [23].

However, industry affiliation is not enough to form a highlevel $\mathrm{HC}$, which requires a number of additional conditions:

- careful examination of the needs and hidden needs at the territorial consumer level;

- live creativity and innovation, including in the process of designing and creating a product, as well as in its promotion and sale, that is, when communicating with customers;

- value, which is the basis of value added, can be created only by the team and its synergies.
The quality formation and sustainable development of the $\mathrm{HC}$ at the regional level is ensured, first of all, by the creation of an enabling environment. The value of labor returns depends on the professionalism of management, the quality of management activities, the level of development of competencies of workers and labor collectives, the value of the accumulated HC [24] and the degree of its use in the region.

It should also be borne in mind that the $\mathrm{HC}$ is formed through individual and public investments, and its functioning has a certain effect on the socio-economic development of the region.

Productivity and quality of work depend on the volume of investments directed and used to ensure the effective implementation of professional skills and production skills of employees, their legal and social protection. At the same time, the prerequisites for the emergence and sources of investment, the peculiarities and mechanisms of their accumulation, as well as changes in the number and nature of work put into motion by them, depend significantly on the strategy of using investments, forms and methods of organizing labor, the distribution of functions in the workplace, and the conditions of production that form productive work. The possibility of economic growth of the territory depends on the formation, development and implementation of the RHC [25].

The proposed RHC assessment methodology is based on the following provisions:

1) RHC is estimated in value terms;

2) take into account the sectoral structure of the regional economy in terms of value added (such sectors include: machine and instrument engineering, electronics, fine chemical technologies, food industry, biotechnology);

3) the value of investments in education is given to date taking into account the index of growth in the cost of educational services;

4) a system of corresponding step-down and step-up coefficients is used.

The RHC value in this case is determined by formula (1):

$\mathrm{RHC}=(\mathrm{It}+\mathrm{Ib}+\mathrm{Ip})(1+\mathrm{Ks}) \mathrm{Kq} \mathrm{Kt}$,

where It - investment in RHC at the regional level, Ib investment in RHC at the employer level; Ip - investment in private education and training, personal and family; $\mathrm{Kt}$ - is the ratio of cost reduction to the current time, coming from the increase in the cost of educational services for the analyzed period; Ks - structural coefficient, reflects the share of employees in industries with high added value of the total number of employees in the region; $\mathrm{Kq}$ - is the aggregate RHC including the up and down factors.

In the framework of the proposed methodology, we consider the optimal use of three lowering and three increasing coefficients (Table 1).

The composition of RHC factors may vary depending on the evaluation objectives and data availability.

Here are some results of the assessment of the RHC of the Belgorod region according to the methodology proposed in the work (Table 2). The coefficient of value creation $(\mathrm{kc})$ is taken at the level of the average value for developed countries, but this should be considered an ideal (desired) value. 
A number of authors believe that the cost of treating and preventing diseases, that is, health care, should also be included in the amount of investments in RHC, but this is a controversial point. For management purposes, the RHC should not be overstated, including «living» costs - food, entertainment, transportation, etc., as this takes away from the economic meaning of the category.

Another thing is that it is worth comparing an investmentquality estimate with the income received by RHC carriers, calculating its profitability.

As we can see, the greatest difficulty is obtaining the kc coefficient, which is responsible for the value-creating abilities of the employee. We need special tests and the development of the corresponding system of metrics: intuition, attention resource, creativity, self-motivation and others. This should be the focus of further interdisciplinary research in the formation and development of RHC. Expert assessments are applicable and the views of managers are taken into account. It should also be borne in mind that at the present stage of the development of the economy, the $\mathrm{HC}$ and the «driver groups» (entrepreneurs, scientists, artists) are becoming the main factor in the development, especially in the conditions of clustering and innovative development of Russian regions [29].

TABLE I. COMPOSITION AND CONTENT OF RHC QUALITY AND INNOVATION FACTORS

\begin{tabular}{|c|l|l|}
\hline $\begin{array}{c}\text { Designation of coefficients, in } \\
\text { fractions of units }\end{array}$ & \multicolumn{1}{|c|}{ Semantic content of coefficients } \\
\hline \multicolumn{2}{|c|}{ Decreasing coefficients } \\
\hline $\mathrm{ka} \leq 0$ & $\begin{array}{l}\text { Share of age workers in total number of employees } \\
\text { (over 50 years) }\end{array}$ & $\begin{array}{l}\text { Statistical reporting on the work of enterprises and } \\
\text { organizations }\end{array}$ \\
\hline $\mathrm{kh} \leq 0$ & $\begin{array}{l}\text { Share of workers with chronic diseases or taking } \\
\text { more than 2 sick days per year }\end{array}$ & Medical and insurance statistics \\
\hline $\mathrm{k} \leq 0$ & $\begin{array}{l}\text { Share of offenders of labor discipline (having more } \\
\text { than 3 violations per year) }\end{array}$ & $\begin{array}{l}\text { Data on personnel services of enterprises and } \\
\text { organizations of the region }\end{array}$ \\
\hline & \multicolumn{2}{|c|}{ Increasing coefficients } \\
\hline $\mathrm{kin} \geq 0$ & $\begin{array}{l}\text { Share of inventors and innovators holding patents } \\
\text { in the total number of employees holding patents }\end{array}$ & Patent Office Data \\
\hline $\mathrm{kr} \geq 0$ & $\begin{array}{l}\text { Share of employees with personal brand, name, } \\
\text { service mark }\end{array}$ & $\begin{array}{l}\text { Data of personnel services of enterprises and } \\
\text { organizations of the region, Chamber of Commerce and } \\
\text { Industry }\end{array}$ \\
\hline $\mathrm{kc} \geq 0$ & Share of employees with value-creating abilities & Test data according to special methods \\
\hline
\end{tabular}

TABLE II. RESULTS OF THE APPROXIMATE ASSESSMENT OF RHC IN BELGOROD REGION

\begin{tabular}{|c|l|c|}
\hline № & \multicolumn{1}{|c|}{ Evaluation item } & Values \\
\hline 1. & Total expenditures of the federal and regional budgets on education (It) & 29,2 billion rubles. \\
\hline 2. & Total expenditures for staff training, development and recreation (Ib) & 9,8 billion rubles. \\
\hline 3. & Expenditure of families and individuals on special and higher education (Ip) & 61,4 billion rubles. \\
\hline 4. & $\begin{array}{l}\text { Coefficient of cost reduction to the current time, coming from the increase in the } \\
\text { cost of educational services for the analyzed period (Kt ) }\end{array}$ & 11,3 \\
\hline 6. & $\begin{array}{l}\text { Percentage of employees in high value-added industries from total number of } \\
\text { employees in the region }\end{array}$ & 0,34 \\
\hline 7. & Age factor (ka) & (Ks =1,34) \\
\hline 8. & Health ratio (kh ) & $-0,19$ \\
\hline 9. & Labour discipline ratio (ko) & $-0,17$ \\
\hline 10. & Innovation factor (kin) & $-0,06$ \\
\hline 11. & Reputation and Goodwill ratio (kr ) & $+0,02$ \\
\hline 12. & Value creation factor (kc) & $+0,03$ \\
\hline 13. & Aggregated quality coefficient RHC (Kq) & $+0,10$ \\
\hline 14. & Region's human capital (RHC) & $0,73(1+0,02+0,03+0,10-0,19-0,17-0,06)$ \\
\hline $\begin{array}{l}\text { Note: The calculation was made for a period of 40 years, based on the period of «able-bodied» time }- \text { from } 18 \text { to } 58 \text { years. } \\
\text { Sources: [20], [26], [27], [28], sample survey of enterprises of Belgorod region. }\end{array}$ \\
\hline
\end{tabular}

Given that the gross regional product for 40 years amounted to 26.4 trillion rubles, taking into account indexation, the gross income on human capital amounted to about 21 rubles/rub. Note that in 2020, the gross regional product (GRP) of the Belgorod region will amount to 900 billion rubles according to experts, and in 2021 its growth is projected, and the value will be over 1 trillion rubles. The region is the leader in this indicator in the Central Federal District of the Russian Federation. The task of further studies of regional management is to identify the correlation between the growth of GRP and the qualitative change in RHC.
The assessment of the RHC level and measures to improve its quality include the main stages that are carried out in a certain sequence [30]:

- establishing the frequency of monitoring of the main indicators of the quality and innovation of human capital; data;

- organization, receiving and processing of the received

- identification of factors contributing to the improvement or deterioration of the quality and innovation of human capital; 
- justification and development of proposals for the rational use of human capital;

- preparing recommendations to the authorities on the implementation of the developed proposals;

- timely information to the authorities on the state of RHC.

In general, two interrelated components can be distinguished in the composition of the RHC - actual and strategic capital. The actual RHC is the human capital of the territory formed at a certain point in time. Strategic RHC is seen as the amount of human capital in the Territory that can be achieved in the future, subject to its best use. At present, the «human capital development model» has not yet been fully created, so often strategic plans for regional development may not be implemented due to the peculiarities of the domestic labor market, the lack of incentives for professional and personal development, higher skills and labor productivity, etc. [31].

\section{CONCLUSION}

Thus, it should be noted that in the context of developed capital markets, the $\mathrm{HC}$ becomes the final resource for regional development and competitiveness. It is the $\mathrm{HC}$ that is the fundamental factor of economic growth in the regions of our country, capable of ensuring their competitiveness in the future.

The development of Russian territories in the medium term (2020-2025) will be influenced by a number of factors that are stronger than the state and use of RHCs, such as maintaining their low investment rating and low level of competition in the regional economy. Nevertheless, it is necessary to identify regional priorities in the field of the formation and reproduction of RHCs, identify "growth points» that need to be maintained even in a tight budget situation, and continue to optimize education and health systems. The HC, determining the qualitative and quantitative composition of labor resources of a certain territory or region, the system for the development of professionalism, intelligence, skills and skills, tools of intellectual and organizational labor, is the foundation of economic development.

At the same time, the RHC assessment has the most important national economic significance, serving for the purposes of strategic territorial management and planning investments in the reproduction of resources at the meso-level. The qualitative and quantitative approach to this assessment, which most clearly reflects the innovation and investment component of the RHC, makes it possible to more accurately determine the state of these resources in the region, to identify weaknesses in their innovative aspects, which are necessary in the new economy, to outline strategic steps regarding the development of human capital: educational policy, forms of supporting unique abilities and new competencies, HR management, creating a creative atmosphere and conditions for the development of unlimited opportunities for the socalled «innovative person» in the 21 st century.

\section{ACKNOWLEDGMENT}

The study has been prepared in the framework of the state task of the Russian The Ministry of Science and Higher Education (0625-2020-0016).

\section{REFERENCES}

[1] V.I. Supruna, Innovative person and innovative society, Novosibirsk, FSPI Trends, 2012, $424 \mathrm{p}$

[2] Yu.N. Bozhkov, Formation of an innovative system for managing the human capital of an industrial enterprise: autoref. dis.... Ph.D. in economics, Belgorod, 2015, 24 p.

[3] G.S. Becker, Human Capital: A Theoretical and Empirical Analysis, N.Y., Columbia University Press for NBER, USA, 1964.

[4] T. Schultz, Investment in Human Capital: The Role of Education and of Research, N.Y., USA, 1971.

[5] M. Blaug, "The Empirical Status of Human Capital Theory: A Slightly Jaundiced Survey", Journal of Economic Literature, vol. 14, No.3 (Sep.), 1976, pp. 827-855.

[6] Z.M. Holboeva, "Human capital of the region: essence, structure and development factors", Bulletin of the Tajik National University. Series of socio-economic and social sciences, no.2/8 (215), 2016, pp. 49-53

[7] I.N. Petrykina, Methodological approach to assessing the level of human capital development in the region and its testing, VSU Bulletin: Series of Economics, 2014, no.1

[8] L.A. Migranova, M.S. Toksanbaeva, "Human potential of the population of Russian regions: level and dynamics of development (part one)", Living standards of the population of the regions of Russia, vol 14, no.2, 2018, pp. 47-59

[9] S.A. Ayvazyan, M.Yu. Afanasyev, "Econometric model of human capital, Review of applied and industrial mathematics", 2010, vol.16, no. 4 , pp. $32-44$

[10] B.I. Rassadin, A.N. Khvaja, National Wealth: Russian Federation USA, Service+, №4, 2019. URL: https://cyberleninka.ru/article/n/ natsionalnoe-bogatstvo-rossiyskaya-federatsiya-ssha/ (accessed 27.10.2020).

[11] N.M. Rimashevskaya, Quality of human potential in an innovative economy, Population, no.3, 2009. URL: https://cyberleninka.ru/article/n/ kachestvo-chelovecheskogopotentsiala-v-usloviyah-innovatsionnoy-ekonomiki/) (accessed 27.10.2020).

[12] I. Soboleva, The human potential of the Russian economy in the context of globalization, Bulletin of the Institute of Economics of the Russian Academy of Sciences, No.1, 2009. URL:https://cyberleninka.ru/article/n/chelovecheskiy-potentsialrossiyskoy-ekonomiki-v-kontekste-globalizatsii/(accessed 23.10.2020).

[13] Al-D. Haider, Methods of financial evaluation of intellectual capital: Russian and foreign experience, Bulletin of SUSU. Series: Economics and Management, no.3, 2018. URL: https://cyberleninka.ru/article/n/metodiki-finansovoy-otsenkiintellektualnogo-kapitala-rossiyskiy-i-zarubezhnyy-opyt/(accessed 23.10.2020).

[14] A.A. Shabunova, G.V. Leonidova, "Human capital - an indicator of sustainable development of the territory, Economic and social changes: facts, trends, forecast”. no.5 (17), 2011, pp. 101-115

[15] [15] M. Pedrini, "Human capital convergences in intellectual capital and sustainability reports", Journal of Intellectual Capital, vol.8, no.2, 2007, pp. 346-366.

[16] O.V. Zabelina, T.M. Kozlova, A.V. Romanyuk, "Human capital of the region: problems of essence, structure and assessment", Economics, no.4, 2013, pp. 52-57

[17] V.I. Martsinkevich, I.V. Soboleva, Human Economics: a textbook, Moscow, Aspect Press, 1995, 216 p.

[18] Mead Douglas, "Indicator of real value added: problems of interpretation and estimation':,Per. from the English, Forecasting problems, no.3, 2010, pp. 33-54

[19] Tax Code of the Russian Federation. URL: http://www.consultant.ru/document/cons doc LAW 19671/ (accessed 27.10.2020)

[20] Methodological provisions on statistics. Item 4.3.1. Retrospective recalculations of production dynamics in the context of economic activities according to OKVED. URL: https://rosstat.gov.ru/ bgd/free/B99_10/IssWWW.exe/Stg/d040/ii\%204-3-1.htm_(accessed 27.10.2020).

[21] I.V. Somina, "Methodology and methodological aspects of estimating economic efficiency in the field of innovation", Bulletin of BSTU named after V.G. Shukhov, No.4, 2013, pp. 142-145 
[22] J.B. Arthur, "Effects of Human Resource Systems on Manufacturing Performance and Turnover", The Academy of Management Journal, vol. 37, no. 3, 1994, pp. 670-687.

[23] Campbell McConnell, Stanley Brue, Sean Flynn, et al., Economics: Principles, Problems, \& Policies, McGraw-Hill, 2018.

[24] J. Mincer, The Production of Human Capital and The Lifecycle of Earnings: Variations on a Theme, Working Paper of the NBER, no 4838, 1994.

[25] S.V. Kupriyanov, A.S. Troshin, I.S. Sandy, E.A. Stryabkova, "Investment process development: principles and characteristics", International Journal of Pharmacy and Technology, vol. 8, no. 4, 2016, pp. 24848-24855.

[26] ] N.V. Bondarenko, L.M. Gokhberg, N.V. Kovaleva, et al., Education in numbers: 2019: short statistical collection Higher School of Economics, Moscow, 2019, 96 p.

[27] Statistical yearbook. Belgorod region: 2019, Belgorod, Russia, 2019, 600 p. URL: https://belg.gks.ru/storage/mediabank/0109_2019.pdf/_accessed 23.10.2020).

[28] Consolidated budgets of the constituent entities of the Russian Federation and budgets of territorial state extrabudgetary funds. Information of the official website of the Federal Treasury. URL: https://roskazna.gov.ru/ispolnenie-byudzhetov/konsolidirovannyebyudzhety-subektov/(accessed 23.10.2020).

[29] I.A. Slabinskaya, E.A. Stryabkova, "Cluster policy and prospects for the innovative development of Russian regions", Economics and management: problems, solutions, no. 7, 2013, pp. 28-34

[30] A.S. Troshin, S.V. Kupriyanov, I.S. Sandu, Investment and innovative component of strategic development of the region (on the example of the Belgorod region): IOP conference series: earth and environmental science, The conference proceedings. Far Eastern Federal University, 2019.

[31] G.R. Nasir, I.N. Titova, A.S. Glotova, A.S. Troshin, "Predictive models and scenarios of economic development of the region". Economic and Social Development Book of Proceedings, 2019, pp. 1143-1149. 